DOI: $10.17805 /$ zpu.2016.1.4

\title{
Духовность и интенции свободного выбора: критический анализ современности
}

\author{
М. В. ШУГУРОВ \\ (САРАТОВСКАЯ ГОСУДАРСТВЕННАЯ ЮРИДИЧЕСКАЯ АКАДЕМИЯ)
}

Статья посвящена детальному исследованию соотношения таких философских категорий, как духовность и свобода, применительно к современной социокультурной ситуации. Большое внимание уделено философскому анализу духовности как свободному смыслообразованию.

Квинтэссенцией авторского подхода является понимание свободы как духовного бытия, устремленного к высшим смыслам. В свою очередь, свобода выбора рассматривается прежде всего как способность следования тем или иным вариантам образования смыслов. Одновременно автор фокусируется на проявлении современной тенденции нисходящего смыслообразования, приводящего к кризису духовности и, соответственно, культуры, а также самоутверждению человека в качестве существа, чуждого миру и другому человеку. Результатом данных процессов выступает деформация свободного выбора.

Необходимо выходить из состояния рассогласования духовности и свободы. Для этого автор акцентирует потенциал философской мысли, способной прогнозировать результаты негативного свободного выбора. Философия может указать человеку путь к подлинному, духовному бытию. В дополнение к этому обосновывается, что сама философия должна задуматься над созданием условий для такой модели социальной, межличностной и межкультурной коммуникации, которая содействовала бы возвращению актов свободного выбора к их духовной основе.

Ключевые слова: свобода; свобода выбора; проблема выбора; духовность; современная культура; философия; постмодерн; европейский рационализм

\section{ВВЕАЕНИЕ}

Б езусловным ценностным основанием современного общества является свободный выбор, который воспринимается в качестве способа реализации свободы. Тем не менее свобода и свободный выбор как аксиоматичные ценностные приоритеты сознания современного человека представляют собой чрезвычайно проблемный феномен. При достаточно глубоком философско-рефлексивном проникновении за фасад многообещающих фантомов техногенной цивилизации и политической демократии, позволяющих наращивать материальные и информационные ресурсы социального и индивидуального бытия, провозглашаемая свобода оказывается недостаточно «свободной», если не сказать более - ущербной. Поэтому далеко не случайно, что содержательные метаморфозы свободы находятся в поле повышенного внимания современной философской мысли (Соколова, 2014; Шорохова, 2014; Пархоменко, 2012; Сидорина, Полянников, Филатов, 2008; Бондырева, Колесов, 2007; Мальцева, 2005).

Феномен свободы, характерный для современного человека и общества, казалось бы, настолько всесторонне отрефлексирован, что сказать что-либо новое по этому вопросу крайне сложно. Тем не менее новое знание вполне возможно, если поместить анализ феномена свободы в контекст размышлений о перипетиях духовного развития современного человека и общества. В этом аспекте достаточно интересными и эвристически ценными являются работы, посвященные философскому анализу феномена Ауховности (Поликанова, 2015; Аелокаров, 2014; Пашков, 2014; Янковская, 2014; Штумпф, 2014; Стерледева, Стерледев, 2013; Аралова, 2012; Нижников, 2012; Филатова, 2011; Усова, 2005; Аившиц, 1997). Представляется, что соединение воедино анализа двух фундаментальных философских категорий позволяет более точно и детально диагностировать изменения, происходящие в бытии современного человека. 
В качестве гипотезы исследования выдвинем положение о том, что причина осуществляющейся деградации свободы, а с нею и деформации человеческого бытия закдючается в редуцировании данного многогранного феномена, представляющего собой квинтэссенцию сущностной духовности человека, к акту выбора предлагаемых товаров, услуг, разного рода кандидатов, образа жизни и т. А. В ситуации отрыва от субстанциальной духовности, которую следует понимать в качестве процесса смыслообразования, свобода угасает в поверхностном выборе, тонущем в пространстве меркантильных интересов. В результате деформируется и сам выбор, представляющий собой основной экзистенциальный «нерв» свободы. В контексте сказанного предметом исследования данной статьи выступает анализ современных деформаций смыслообразования, приводящих к «торжеству» ограниченной модели свободы, характерной для современного человека и общества, главным образом в их западном варианте.

\section{МЕТАМОРФОЗЫ СВОБОАЫ СКВОЗЬ ПРИЗМУ АУХОВНОСТИ}

В условиях глобализации свобода стала әлементом современного образа жизни, и любое ее ограничение рассматривается как посягательство на святая святых. С точки зрения обостренного чувства свободы, связанного с беспрецедентной индивидуализацией и анархизацией человека, подкрепляемой современной идеологией прав человека, многое видится и рассматривается как препятствующее утверждению воли к свободе, ныне не знающей границ и приводящей к усилению духа критицизма. Как точно отмечает А. Азоло, повышение дифференциации и колоссальное распространение мобильности, знаний и возможностей для нового опыта, происходящее благодаря технологическим новшествам, резко обостряет потребность в функциональной свободе и личной независимости. «В результате, - пишет он, - образуется эрозия публичного измерения социальной жизни и личной независимости. Как итог, сверхсложная социальная система с трудом поддается управлению» (Азоло, 2010: 311-312).

При этом не следует забывать, что предельной антропологической константой человека является духовность. Это своего рода сущность первого порядка, тогда как свобода - сущность второго порядка, конкретизирующая содержательную сторону духовности. Как известно, философские категории «свобода» и «духовность» являются неисчерпаемыми по своему содержанию, что вполне заметно по хорошо известному факту многообразия концептуальных образов данных феноменов. Если за отправную точку отсчета принять герменевтический подход к человеку как к «понимающему существу» (Шугуров, 2013), то духовность предстанет в качестве способности смыслообразования, или «уразумения». Именно данная способность - наиболее выразительная сущностная черта человека, благодаря которой он утверждает себя в качестве субъекта культурного бытия.

При этом духовность как способность и реальность смыслообразования представляет собой движение сознания в различных направлениях, что задает неисчерпаемую объемность мира смыслов и ценностей, в которых живет человек и из которых он произрастет. Аанная многомерность, определяемая свободой духа, результируется в многообразии культурного ландшафта человеческого бытия, в том числе в неистощимом многообразии философских учений. Наличие векторов смыслообразования, или понимающих движений сознания, генерирующих смыслы как некие кванты понимания, говорит в пользу наличия свободного выбора в качестве «приводного» механизма понимающего бытия человека. Одновременно свободный выбор в пространстве смыслообразования может означать интенциональные траектории, ведущие как 
к образованию возвышенных, сокровенных смыслов, так и смыслов вполне банальных и обыденных, что, в сущности, характерно для любых культур. Но так или иначе человек - многогранное существо, а человечество - разнородно в своих предпочтениях. Это приводит к обособлению внутри духовности разнообразных - сгущенных и разреженных - слоев, смыслового верха и смыслового низа, что создает напряженное поле культурных смыслов.

В силу абсолютного характера свободы духовной сферы человека свободный выбор векторов смыслообразования и выбор предпочитаемых, уже сформированных смыслов сочетается с возможностью трансгрессии, т. е. свободного выбывания из сферы смыслов. Разумеется, тотальная смысловая трансгрессия означает самоаннигиляцию человека. Однако движимые чувством сохранения те или иные индивиды и сообщества не могут пойти на полное самоупразднение в порыве возникшего некоторого смыслового вихря и погружаются в сумеречную зону угасания осмысленного бытия - в смысловой меон, наполненный смысловыми суррогатами, тенями и деформациями. Суть смысловой трансгрессии - нигилистическое отрицание, чуждое отрицанию, являющемуся элементом творческого процесса. Выбор вектора самовычеркивания из духовности не является беспричинным. Он, как представляется, является результатом ослабления связи с высшими смыслами и размягченного сползания в смыслы повседневные. Таким образом, искушение смысловой трансгрессией, которая в религиозной терминологии может быть оценена как грехопадение и апокалипсис, суть ослабление воли к смыслу (максимально әнергийным усилиям осмысления) и стремление к иному - постбытийному - позиционированию.

Где и когда происходит данная трансгрессия, сопровождающаяся «уплощенем» свободы и деформацией свободного выбора ввиду разреженности смыслообразования и характеризующаяся как онтологическое зло неподлинного бытия? Она происходит не только в сфере возможности - как некое метафизическое событие, но и в рамках вполне конкретных социокультурных ситуаций. Взять хотя бы феномен так называемого современного искусства, неспособного создавать и выражать некие фундаментальные смыслы. В вихревое сползание за нижнюю смысловую границу духовности оказываются вовлеченными и социальные связи, и различные сферы социального бытия. Все это требует, во-первых, адекватной диагностики происходящего, во-вторых, проектирования конкретных мер, что невозможно осуществить вне философской рефлексии, чудом сохранившейся в условиях современного смыслового апокалипсиса.

Рассматриваемые процессы, происходящие в сфере свободного человеческого духа, понятого как сфера свободного смыслообразования, находятся в основании трансформаций внешней свободы, достаточно податливой для социокультурного понятийного мониторинга. Поэтому, если исходить из предложенного нами категориального видения феноменов духовности и свободы, то отмеченные в самом начале статьи метаморфозы свободы можно отнести к результатам ноогенной трансгрессии. Последняя проявляется, в том числе, и в распаде связи свободы и духовности, когда свобода начинается пониматься как тривиальные акты выбора, но не как творческие акты осмысления человеком самого себя и окружающего его мира в пространстве диалога культур. Вследствие этого свободный выбор перестает конституироваться в качестве выбора духовного. Обнажается изнанка свободного выбора: он - все что угодно, но только не способ реализации подлинной духовности, представляющей собой энергийное стремление к высшим смыслам и их формированию. Аишенный духовной 
почвы свободный выбор, развертывающийся также на уровне социальных связей и отношений, утрачивает подлинность своего содержания, становясь сводным выбором несвободы, и обретает черты квазифеномена.

В духовности как возможности раскрытия имеющихся смыслов или их образования, включая формирование недостающих смыслов, заключен главный источник культурного саморазвития человека. Жизнь смысла, слагающаяся из воспроизведения и творчества, - необычайно широкое поле свободы выбора как способов интерпретации, так и феноменов, подлежащих осмыслению. В пространстве духовности человек находится на стезе возможности возвышения понимания. Это является условием возможности адекватной оценки и разрешения проблем, возникающих в жизни человека и общества. Вне и помимо духовной работы смыслопрояснения - накопление критической массы неразрешенных проблем, стержень которых составляет проблема смысла.

Анализируемые процессы метаморфоз свободы в пространстве кризиса духовности вполне обоснованно можно охарактеризовать и как процессы кризиса культуры. В условиях кризиса культуры, по крайней мере культуры европейской, в основе которого - кризис новоевропейского типа рациональности, философская мысль призвана совершить усилие по диагностированию направления и содержания самоопределения человека в поле свободного выбора. Именно желание и способность человека в процессе выбора оставаться и быть свободным во многом определяет специфически человеческую форму и содержание существования - культуру. Само пространство выбора и процессы, в нем происходящие, есть тяжба между гуманизацией и дегуманизацией человека, между собственно человеческим и теневым (квазичеловеческим) существованием.

\section{УГАСАНИЕ АУХОВНОСТИ КАК ВЫБОР «СВОБОАЫ БЕЗ СМЫСАА»}

Вопрос о смысле бытия человека в мире в конечном счете относится к открытым и к тому же - вечным вопросам. Однако обращенность к нему - безусловная интенция духовности, позволяющая обосновать возможность человеческого бытия как возможность осмысленного бытия: трансцендирование в невозможное открывает возможное. В противном случае возникает нагромождение псевдосмыслов, которые сулят возможность существования, но на деле удушают, делая осмысленное существование невозможным. На уровне социокультурной эмпирии происходит не только падение нравов, но и деградация человека, его дегуманизация. Надо сказать, что от данных процессов исходит мощная волна испытания надежности смысло-духовных скреп в форме постановки под сомнение иного - позитивного - состояния человека. Ключом к осмыслению этих проблем является их истолкование в качестве онтологического выбора. Свобода, угасающая в выборе, - символизация выбора свертывания духовности как модуса осмысленного бытия. Свертывание духовности имеет такие негативные последствия, как декультурация, дегуманизация, ориентация на смысловую поверхность.

Ослабление бытия в культуре и выход за его рамки может увлечь за собой и философию. Так, если присмотреться к внешним очертаниям и содержанию постмодернистского пространства свободы выбора, то осуществляемое стремление к коллажной поверхности и реальности, конструируемой методом аппликации, предполагает известное вытеснение человека из культуры, а точнее - миграцию из центра на периферию, где процессы синтеза смысла крайне затруднены. На периферии смыслообра- 
зования духовность теряет свою интенсивность, хотя декларирование свободы выбора культурных ориентаций становится все более и более выпуклым и даже навязчивым. Аанные процессы есть кризис, а именно самопроблематизация рациональной культуры. Возобладание виртуального над реальным, периферии над центром, наркотизация сознания и т. А. - плод упорного игнорирования необходимости взаимодействия центра и периферии, отчетливого и смутного понимания. Ауховность - это всегда напряженное бытие на границе с другим, взаимоуподобление и взаимопонимание. При однозначном выборе либо центра, либо "размягченной» периферии возрастает аутизм: отсутствуя в поле дискуссии и полемики, человек исчезает и «стирается». ОАнако в этом событии происходит и нечто большее - само существование духа становится невнятным. Но взлеты и падения в одинаковой мере - предикаты человеческого духа: он раскрывает свою тайну не только в торжественном шествии, но и в болезненных расстройствах и внутренних разладах.

Аля характеристики современного общественного и индивидуального сознания весьма часто используется термин «бездуховность». Аанное обозначение не следует тем не менее воспринимать в прямом смысле слова: бездуховность - это духовность с обратным знаком. Поэтому использовать в качестве синонима термин «недуховность» неуместно, так как он означает не отрицательную направленность духовности, а вообще ее отсутствие как таковой. Однако духовность - непременный атрибут человека; в ее состояниях как определенных модусах сознания заложены основания конкретных способов бытия человека в мире.

При ослаблении порывов духа, т. е. при ослаблении смыслообразования, духовность, а с нею и все человеческое существование вступает в полосу кризиса. «Кризис»- термин, наиболее адекватно и точно выражающий суть современной ситуации, обнаруживающейся в целом ряде однопорядковых явлений, таких как отрыв от бытийственных корней, пессимизм, бесперспективность, нравственный релятивизм, разочарование в основных постулатах культуры, разрушение веры в гармонию мира и исторический прогресс, а также в незыблемость духовных ценностей. Отрыв личности от онтологических корней, в частности, привел к возникновению феномена массы, закрепляющего своеобразное решение проблемы личностного существования в полном отказе от Я. Нарастание бездуховности в указанном смысле слова еще не приняло необратимого характера, хотя одной из перспектив кризиса является катастрофа. Сознание, вступающее в предкатастрофическую ситуацию, утрачивает функции различения. Неразличающее инертное сознание творит вокруг себя хаос. Ауховность же - некая глубинная структура сознания, позволяющая ограничивать хаос и индивидуализировать все из него высвобождаемое.

Аолгое время духовность сводилась к содержанию факта сознательной деятельности. Ныне со всей критичностью приходится признать, что сам факт наличия сознательной деятельности и рациональности тех или иных жизненных процессов еще не есть показатель аутентичной духовности. Наличие сознательной деятельности может быть совместимым и с отрицательной духовностью, т. е. «схлопыванием» (свертыванием) смыслов. Разве не падший дух активно завоевывает природу и создает искусственные среды существования человека? В итоге субъект социокультурной деятельности, действуя рационально и сознательно, еще не становится на этом основании субъектом духовным.

Ауховность как особое актуальное переживание не может реализовываться по частям; ее непосредственное, необъективируемое бытийствование (и в известном смыс- 
ле - непредикативность) обнаруживается и осуществляется в феноменологическом поле личности и требует иных, чем методы объективного научного познания, средств постижения. И все же она не есть нечто всецело тайное, сокрытое и неявное. Так, в феномене ценности достигается определенный уровень явленности духовности как смыслополагания. Ценность в этом случае выступает не столько целеориентирующей интенцией сознания, сколько горизонтом, задающим понимание тех или иных явлений и процессов. Хотя ценностное содержание сознания индивидов, групп, того или иного общества в целом может быть весьма далеким от всего богатства содержательного объема духовности, оно все же так или иначе ее реализует. В ценностном сознании, напрямую соотнесенном с духовностью, сознание приобретает различные качественные характеристики, демонстрируя тем самым разновекторную архитектонику духовности. «Ауховность, - замечает по этому поводу В. Г. Федотова, - есть качественная характеристика сознания (как и поступка, дела, жизни), или, точнее, характеристика его разнокачественности. Характеристика эта отражает господствующий тип ценностей, и поэтому духовность не есть нечто единое» (Федотова, 1987: 25).

На наш взгляд, ценности суть экспликации духовности, не исчерпываемой, однако, суммой форм ее проявления. Непроявленное - тот энергийный континуум, в рамках которого автономный и свободный субъект осуществляет судьбоносный акт выбора как акт свободной реализации тех или иных содержательных контуров духовности - начиная от высших форм смыслополагания и заканчивая допущением и тиражированием поверхностных смыслов, репрезентирующих вакуум и разряженность Ауховности.

В духовности как не только напряженной соотнесенности человека с некими константными, т. е. своего рода заданными высшими смыслами, но и как творческом процессе смыслополагания и (или) смыслообразования претворяется событие осуществления открытости человека миру. Аумается, что открытость - это важнейшее качество духовности, выражающееся в обращенности идеальной сферы смыслов к миру человеческого бытия. Необходимо учитывать, что открытость человека миру исключительно бифуркационна в отношении самой себя: здесь царит свобода изменения и выбора параметров открытого позиционирования. Но если свобода может заканчиваться свободой выбора, то духовность как основание свободы практически не ограничиваема никакими рубежами свершенности: свободно выбирая даже негативный вектор открытости, человек, становясь несвободным, не перестает от этого оставаться духовным существом, хотя и духовным с отрицательным знаком, чему соответствует символика падшего духа.

Самоопределяясь в качестве существа, чуждого миру, т. е. существа со «свернутой» открытостью, человек экспериментирует с освоением нижней границы своего собственного бытия - вдавленности духовности в собственную невыраженность и даже кажущееся полное отсутствие. Мы полагаем, что духовное самообоснование в качестве «чуждого» не только реанимирует те или иные вытесненные агональные взаимодействия, но главным образом десублимирует прошедшие аккультурацию формы отчуждения. С учетом технологической оснащенности человека самообоснование на путях духовности, практически сведенной к нулевой отметке и вытесненной в координаты отрицательных величин, почти не способно оставить шансы конструктивному бытию, весь пафос которого заключает в нацеленности на смыслообразование.

История культуры знает и такой способ утверждения практически безграничной свободы, как карнавал. Карнавал - это не только достояние стародавних культур, но 
и, по признанию искусствоведов, сердцевина творческого метода Нового времени (Батракова, 1996: 59). Карнавал - поистине праздник выбора, но каково его соотношение с духовностью? Необходимо признать, что духовность шире карнавального духа, снимающего запреты и тяготеющего к вседозволенности.

Чрезмерные притязания и утрата онтологической скромности, а главное - духовная «смятость» и смятение постепенно создают в каркасах смешного нечто ужасное то, что после человека. В условиях дефицита возможностей нормального самоутверждения гражданских качеств, таких как суверенность, достоинство, ответственность, духовная деградация неизбежно усиливается. Корни социальной деградации, по сути, находятся не только в социальном измерении, но и в глубинах выбора человеком самого себя либо в качестве подлинного духовного существа, либо в качестве его тени, отличающейся патологической недостаточностью смыслов и понимания.

Будучи необходимым условием удовлетворения акультурных потребностей, экзистенциальный разлом не только соседствует, но даже предполагает антиобщественную направленность индивидуальной активности. Отчуждение и отчуждающая от культуры как совместного смыслополагания позиция низводит человека как в социальной, так и (особенно) в духовной жизни до уровня конкретно-ситуативного существа, сжатого в простое звено в цепочке «стимул - реакция». В связи с тем, что именно культура предоставляет возможность духовного и сугубо практического трансцендирования, любое «выскальзывание» из нее означает утрату способности к свободному преодолению ситуации и приобретение поступком сугубо импульсивного, а не смысло-ценностного характера. Уже сама по себе «зажатость» ориентирует на анархо-негативную направленность поведения, приводящую к нереализованности сущностного потенциала человека.

Проблемы, созданные частичной реализацией духовного потенциала, требуют для своего разрешения реализации духовной универсальности. Аюбая пауза в деле возрастания духовности автоматически превращает проблемную ситуацию не в способ движения вперед, а в способ движения назад, приобретающего контуры движения по кругу. На низших рубежах духовности бытие диффундирует в пребывание в безысходных теневых лабиринтах - как социальных, так и культурных, отмеченных дефицитом положительного дела приращения осмысленности. Расчеловечивание происходит и по той причине, что индивид замыкается в лабиринте собственной бессодержательности: ему незачем вступать в экзистенциальное общение с другим человеком, внутри которого точно такая же пустота.

\section{БЕЗАУХОВНАЯ СВОБОАА: ИСТОРИЯ И СОВРЕМЕННОСТЬ}

Не следует думать, что раздухотворение действительно существующих отчужденных отношений между духом и материей, человеком и миром и выдвижение их на передний план стало следствием простого волютивного решения. Выворачивание изнанки духа непосредственно корреспондирует с тем, что новоевропейский человек, наследником которого является человек постсовременный, по вполне объективным обстоятельствам был вынужден вторично пережить кошмар рождения и выделения из мира, когда разрыв с духовными традициями прошлого вверг его в точку максимальной по сравнению с прошлым индивидуальной свободы, но одновременно и минимальной духовности. Самоопределение в мире в качестве чужого, сопровождавшееся возвратом в состояние непонимания (и неприятия) окружающего, было детерминировано объективным переходом от традиционного общества к обществу современному. 
С одной стороны, выбравшись из ячеек традиционного общества с присущими ему «объятиями» партикуляризма, человек, ранее прикрепленный к определенной территории, оказался открыт огромному миру. Привычный круг властвующих и подвластных разомкнулся: возникло неведомое ощущение свободы. Свободный, несмотря на свою масштабность, социальный и природный мир стал восприниматься в качестве своего жизненного пространства. Индивид увидел в себе гражданина мира, его равноправное и необходимое звено. Но помимо небывалой открытости миру, потребности его осмысления и свободного самоопределения в нем по тем или иным направлениям обозначилась и другая сторона, которая со временем стала лидирующей. «Оборотной стороной этой психологии был широкий спектр чувств личности - от настроений отчуждения и одиночества до эгоцентричной бесконтрольности, конкурентного взаимоотталкивания, зависти и т. п.» (Кузьмин, 1997: 63).

Поставленность человека в ситуацию самоопределения и выбора перед дицом безмерного, неохватного мира, на который уже не набрасывалась прежняя религиозная сакральная сетка, задававшая сокровенность понимания, не могла не сказаться на соскальзывании в сторону искушающей возможности отчуждающего самоопределения. Стратегия свободного выбора, исчерпывающего свободу, была концептуализирована в демифологизированном и сциентизированном представлении о мире как картине, ставшем концептуальным фундаментом Нового лабиринта, возводимого не считающейся ни с какими принципиальными ограничениями современной техникой. Началась эпоха господства искусственных образований, для которых традиционные методы самообоснования человека в качестве своего Аругого мира являются совершено потусторонними.

В обстановке XX в., когда скрепы протестантского духовного аскетизма лопнули, возникла фигура примитива, не восприимчивого к подлинно человеческому масштабу духовной открытости. Разложение открытости привело к духовно-смысловому недомоганию и даже к болезненному состоянию ноонервоза. Выбившееся из средоточия старых связей и традиций европейское человечество оказалось в состоянии растерянности, ибо «ведь далеко не всегда благотворно - одним махом взять и порвать с тысячелетними традициями предков, с древними образами, связывавшими с космосом» (Иинденберг, 1997: 17). Старые истины коллективного бессознательного с помощью непреходящих смыслов тысячелетиями поддерживали существование человека. Новые же инстинкты подготовили смысловое банкротство и духовную несостоятельность человека.

Постмодерн как переосмысление истоков и результатов «заносчивой» духовности - своеобразное возвращение к некоторым элементам архаического прошлого с присущими им моментами празднества бытия. Однако в архаике есть пласты, которых лучше не касаться, ибо при соприкосновении с ними духовность не только не обновляется, а окончательно разрушается. Речь идет об архаическом архетипе Чужого. Вызванный к жизни экранной культурой данный прообраз продуцирует в массовом сознании и соответствующую архаическую модель отношения к Чужому.

Вместе с архаикой в состав социально-культурного порядка просачивается и такое однопорядковое явление, как анархия - безрезультативная в своей негативности духовная самоидентификация человека. В социальном плане приветствуемая постмодерном анархизация сознания гипотетически предполагает откат в естественное состояние, где, как известно, сметены ограничительные барьеры. Как отмечает В. Г. Федотова, «анархический, негативно-свободный индивид не может быть авто- 
номным, является зависимым, ограничен в своей инструментальной рациональности, поскольку действует в мире хаоса и персонально дезинтегрирован» (Федотова, 1998: 14).

Существенным препятствием эволюции духовного оскудения в сторону небытия является опыт культуры как опыт превзойдения и ограничения дикой и хаотичной предыстории. Аумается, что всякое обращение к архаике как свободному естественному состоянию вненахождения в смыслополагающем ядре культуры способно увенчаться реальным возвращением в архаику. Всплески архаических импульсов постоянно сопровождали и искушали духовно самоопределяющегося человека (Назаретян, 1993: 90).

В условиях глобализации XXI в. отмеченная выше архаизация, как представляется, удивительным образом сочетается с ультрасовременной сетевой организацией общества, которая, с одной стороны, казалось бы, расширяет возможности коммуникации и смыслообразования, а с другой - содействует утверждению отчужденной самоидентичности человека. Анализируя содержательные трансформации опыта, понимаемого в качестве совокупности информации, переработанной и доведенной до стадии понимания и овладения ею, А. А. Горелов и Т. А. Горелова подчеркивают усиление процессов распада и отчуждения в мире, в котором процессы коммуникации подвергаются объективации: «Сетевая, анонимно-отчужденная и виртуальная структура современной системы коммуникаций внедряется в глубины экзистенциального опыта, в “метастабильное” состояние “трансцендентности-фактичности”... <..> А анонимность и бестелесность “другого” в коммуникативном обмене усиливают отчуждение и отменяют общение в симпатии и любви. Тем самым суживаются границы опыта и достижения истины» (Горелов, Горелова, 2015: 26). С нашей точки зрения, отмеченные процессы говорят о том, что, несмотря на расширение пространства коммуникативной свободы, сама природа последней не приводит к образованию смыслов и, следовательно, ведет к «свертыванию» духовности, а с нею - к содержательному опустошению свободы.

\section{ЗАКАЮЧЕНИЕ}

Кризис духовности делает востребованной критическую работу философской рефлексии, которая в настоящее время стоит перед новыми вызовами и характеризуется В. А. Подорогой как реализация призванности к тому, чтобы служить методологической основой для глобальной «переоценки всех ценностей» (Подорога, 2010: 18). Как и чем философия может воспрепятствовать осуществлению находящегося на задворках культуры негативного свободного выбора духовного самоопределения человека в качестве существа, чуждого миру, т. е. существующего в сумеречной полосе недо-осмысленности? Вероятно, во-первых, через указание на пределы культивируемой постмодерном толерантности как «всеядности» по отношению к различным мировоззренческим позициям, во-вторых, посредством внесения в общественное сознание ярких и выпуклых образов возможного негативного перерождения человека вплоть до антропологической катастрофы, которым должны быть противопоставлены образы преображающегося человека. В этой связи к одному из вновь востребованных ценнейших качеств философии относится ее способность аргументированного различения подлинного и неподлинного бытия. Это связано с ее ответственным признанием и принятием чего-то и кого-то в качестве правого и истинного, что тесно связано с выделяемой У. Кимликой вслед за Аж. Ролзом некой интуицией правильного и неправильного (Кимлика, 2010: 22). 
Аумается, что возрождение духовности связано с принципиальным неприятием негативного выбора, «ловящего» свободу, а также с возрождением в комплексе человеческой духовности страстного искания истины и нравственного долженствования, в горниле которых человек претворяется как дружественное, предрасположенное к миру существо, а свобода воссоединятся с духовностью.

Аружественная позиция, по сути, задает возможность интенсивного совместного смыслообразования, в условиях глобализации предполагающего кросс-культурное смыслополагание в контексте многообразия и плюрализма культур. Благодаря укреплению общей атмосферы коммуникативного доверия и инструментарию ненасильственной коммуникации открывается возможность расширения смысловой вместимости и креативности социокультурного субъекта, а общество приобретает новый ресурс развития в виде признаваемого смыслового разнообразия и плюрализма, являющихся средой для одухотворения свободы как свободного выбора.

\section{СПИСОК АИТЕРАТУРЫ}

Аралова, Е. В. (2012) Ауховность как фактор постижения смысла жизни // Человеческий капитал. № 4 (40). С. 4-8.

Батракова, С. П. (1996) Художник ХХ века и язык живописи: от Сезанна к Пикассо. М. : Наука. 176 с.

Бондырева, С. К., Колесов, А. В. (2007) Суверенитет, субъективность, свобода. М. : Моск. психолого-социальный ин-т ; Воронеж : ИзА. дом РАО. 463 с.

Горелов, А. А., Горелова, Т. А. (2015) Опыт как эволюционный процесс // Знание. Понимание. Умение. № 1. С. 18-28. DOI: 10.17805/zpu.2015.1.2

Аелокаров, К. Х. (2014) Модернизация российского общества и проблема духовности // Социально-гуманитарные знания. № 3. С. 71-87.

Азоло, А. (2010) Аемократия и сложность: реалистический подход : пер. с англ. М. : ИзА. дом ГУ - ВШЭ. 320 с.

Кимлика, У. (2010) Современная политическая философия: Введение : пер. с англ. М. : Изд. дом ГУ - ВШЭ. 592 с.

Кузьмин, М. Н. (1997) Переход от традиционного общества к гражданскому: изменение человека // Вопросы философии. № 2. С. 57-70.

Иившиц, Р. А. (1997) Ауховность и бездуховность личности. Екатеринбург : Изд-во Урал. ун-та. 152 с.

Иинденберг (Челищев), В. А. (1997) Таинство встречи. М. : Крипто-логос. 240 с.

Мальцева, А. П. (2005) Индивидуальность и личность: свобода желания и желание свободы // Человек. № 1. С. 25-32.

Назаретян, А. П. (1993) Технология и психология: к концепции эволюционных кризисов // Общественные науки и современность. № 3. С. 82-93.

Нижников, С. А. (2012) Проблема духовного в западной и восточной культуре и философии. М. : ИНФРА-М. 168 c.

Пархоменко, Р. Н. (2012) Генезис идеи свободы в западноевропейской философии // Философская мысль. № 4. С. 179-210.

Пашков, В. И. (2014) Существенные признаки духовности личности // Образование. Наука. Научные кадры. № 5. С. 164-166.

Подорога, В. А. (2010) Апология политического. М. : Изд. дом ГУ - ВШЭ. 288 с.

Поликанова, Е. П. (2015) Ауховность - главная ценность личности // Культура. Ауховность. Общество. № 16. С. 181-186.

Сидорина, Т. Ю., Полянников, Т. А., Филатов, В. П. (2008) Феномен свободы в условиях глобализации. М. : Рос. гос. гуманит. ун-т. 410 с.

Соколова, В. С. (2014) Свобода потребителя - подлинная свобода? // Молодой ученый. № 14. C. 333-335. 
Стерледева, Т.А., Стерледев, Р. К. (2013) Ауховность и бездуховность как вызов и риски для России // Власть. № 8. С. 78-82.

Усова, Н. А. (2005) Образ человека. Аики духовности: Концептуальные подходы. СПб. : [Ключ] ; Челябинск : Изд-во Челябинск. гос. пед. ун-та ; Полиграф-Мастер. 229 с.

Федотова, В. Г. (1987) Ауховность как фактор перестройки // Вопросы философии. №3. C. $11-28$.

Федотова, В. Г. (1998) Анархия и порядок в контексте российского посткоммунистического развития // Вопросы философии. № 5. С. 3-20.

Филатова, Н. Г. (2011) О концептуальных основаниях изучения феномена духовности // Экономика, финансы и управление в современных условиях : межвуз. сб. науч. ст. Вып. 7 (9) / под ред. А. Н. Сорочайкина. Самара : Изд-во Самарск. гос. ун-та. 234 с. С. 184-192.

Шорохова, М. А. (2014) Свобода выбора и духовная свобода в контексте проблемы качества жизни // Известия Волгоградского гос. пед. ун-та. № 8 (93). С. 54-58.

Штумпф, С. П. (2014) Концептуальная модель духовности: содержательный контент, структура, механизмы реализации // Вестник Красноярского гос. пед. ун-та им. В. П. Астафьева. № 3 (29). C. 178-182.

Шугуров, М. В. (2013) Соотношение смысла и небытия в антропологической онтогерменевтике: культуро-философские проекции // Философия и культура. № 10. С. 1353-1367.

Янковская, А. В. (2014) Ауховность в культуре и философии (в преддверии интегрального синтеза в понимании духовности) // Культура и время перемен. № 3 (6). С. 138-142.

Аата поступления: 23.07.2015 г.

\section{SPIRITUALITY AND INTENTIONS OF THE FREEDOM OF CHOICE: A CRITICAL ANALYSIS OF THE CONTEMPORANEITY \\ M. V. SHUGUROV \\ (SARATOV State LAW ACADEMY)}

The article provides a detailed examination of the correlation between such philosophical categories as spirituality and freedom as applied to the current social and cultural situation. A good deal of attention is paid to philosophical analysis of spirituality as a free process of creating meanings.

The essence of the author's theoretical approach lies in understanding freedom as spiritual existence directed towards the supreme meaning of life. In its turn, freedom of choice is viewed as a capacity to follow one or another version of creating these meanings. At the same time, the author focuses on the emerging trend of descending construction of meanings, which leads to a crisis of spirituality and, accordingly, to a cultural crisis and human self-affirmation as alien to the world and other people. In the end, freedom of choice itself is deformed.

Mankind has to overcome the malalignment between spirituality and freedom. To do that, we have to accentuate the reflexive potential of philosophical thought capable of predicting the outcomes of negative free choice. Philosophy can point out the way to proper, i.e. spiritual existence. Then it has to think of how to provide adequate conditions for a pattern of social, interpersonal and intercultural communication which would help acts of free choice regain their spiritual background.

Keywords: freedom; freedom of choice; problem of choice; spirituality; contemporary culture; philosophy; postmodernity; European rationality

\section{REFERENCES}

Aralova, E. V. (2012) Dukhovnost' kak faktor postizheniia smysla zhizni [Spirituality as a factor of understanding the purpose of life]. Chelovecheskii kapital, no. 4 (40), pp. 4-8. (In Russ.).

Batrakova, S. P. (1996) Kbudozbnik XX veka i iazyk zbivopisi: ot Sezanna k Pikasso [20th century painter and the language of painting: From Cézanne to Picasso]. Moscow, Nauka Publ. 176 p. (In Russ.). 
Bondyreva, S. K. and Kolesov, D. V. (2007) Suverenitet, sub' ektivnost', svoboda [Sovereignty, subjectivity, freedom]. Moscow, Moscow Institute of Psychology and Sociology Publ. ; Voronezh, Publ. House of the Russian Academy of Education. 463 p. (In Russ.).

Gorelov, A. A. and Gorelova, T. A. (2015) Opyt kak evoliutsionnyi process [Experience as an evolutional process]. Znanie. Ponimanie. Umenie, no. 1, pp. 18-28. DOI: 10.17805/zpu.2015.1.2 (In Russ.).

Delokarov, K. H. (2014) Modernizatsiia rossiiskogo obshchestva i problema dukhovnosti [Modernization of Russian society and problem of spirituality]. Sotsial'no-gumanitarnye znaniia, no. 3, pp. 71-87. (In Russ.).

Zolo, D. (2010) Demokratiia i slozhnost': realisticheskii podkhod [Democracy and complexity: A realist approach] : transl. from English. Moscow, Publishing House of the Higher School of Economics. 320 p. (In Russ.).

Kymlicka, W. (2010) Sovremennaia politicheskaia filosofiia: Vvedenie [Contemporary political philosophy: An introduction] : transl. from English. Moscow, Publishing House of the Higher School of Economics. 592 p. (In Russ.).

Kuzmin, M. N. (1997) Perekhod ot traditsionnogo obshchestva k grazhdanskomu: izmenenie cheloveka [The transition from traditional to civil society: The human change]. Voprosy filosofii, no. 2, pp. 57-70. (In Russ.).

Livshits, R. L. (1997) Dukbovnost' $i$ bezdukbovnost' licbnosti [Human morality and the lack thereof]. Ekaterinburg, Ekaterinburg University Publ. 152 p. (In Russ.)

Lindenberg (Chelishchev), V. A. (1997) Tainstvo vstrecbi [The sacrament of meeting]. Moscow, Kripto-logos Publ. 240 p. (In Russ.).

Maltseva, A. P. (2005) Individual'nost' i lichnost': svoboda zhelaniia i zhelanie svobody [Individuality and personality: Freedom of desire and desire for freedom]. Chelovek, no. 1, pp. 25-32. (In Russ.).

Nazaretian, A. P. (1993) Tekhnologiia i psikhologiia: k kontseptsii evoliutsionnykh krizisov [Technology and psychology: Towards the concept of evolutional crises]. Obshchestvennye nauki $i$ sovremennost', no. 3, pp. 82-93. (In Russ.).

Nizhnikov, S. A. (2012) Problema dukbovnogo v zapadnoi $i$ vostochnoi kul'ture $i$ filosofii [The problem of spirituality in cultures and philosophies of the West and East]. Moscow, Infra-M Publ. 168 p. (In Russ.).

Parkhomenko, R. N. (2012) Genezis idei svobody v zapadnoevropeiskoi filosofii [The genesis of the idea of freedom in European philosophy]. Filosofskaia mysl', no. 4, pp. 179-210. (In Russ.).

Pashkov, V. I. (2014) Sushchestvennye priznaki dukhovnosti lichnosti [Essential elements of personal spirituality]. Obrazovanie. Nauka. Nauchnye kadry, no. 5, pp. 164-166. (In Russ.).

Podoroga, V. A. (2010) Apologiia politicheskogo [Apologia of the political]. Moscow, Publishing House of the Higher School of Economics. 288 p. (In Russ.).

Polikanova, E. P. (2015) Dukhovnost' - glavnaia tsennost' lichnosti [Spirituality as the main personal value]. Kul'tura. Dukbovnost'. Obsbchestvo, no. 16, pp. 181-186. (In Russ.).

Sidorina, T. Yu., Poliannikov, T. L. and Filatov, V. P. (2008) Fenomen svobody v usloviiakb globalizatsii [The phenomenon of freedom under globalization]. Moscow, Russian State University for the Humanities Publ. 410 p. (In Russ.).

Sokolova, V. S. (2014) Svoboda potrebitelia - podlinnaia svoboda? [Is the freedom of consumer the true freedom?]. Molodoi uchenyi, no. 14, pp. 333-335. (In Russ.).

Sterledeva, T. D. and Sterledev, R. K. (2013) Dukhovnost' i bezdukhovnost' kak vyzov i riski dlia Rossii [Spirituality and a lack thereof as a challenge and risks for Russia]. Vlast', no. 8, pp. 78-82. (In Russ.).

Usova, N. A. (2005) Obraz cheloveka. Liki dukbovnosti: kontseptual'nye podkbody [Image of man. Faces of spirituality: A conceptual approach]. St. Petersburg, [Kliuch Publ.] ; Chelyabinsk, Chelyabinsk State Pedagogical University Publ. ; Poligraf-Master Publ. 229 p. (In Russ.).

Fedotova, V. G. (1987) Dukhovnost' kak faktor perestroiki [Spirituality as a factor of perestroika]. Voprosy filosofii, no. 3, pp. 11-28. (In Russ.). 
Fedotova, V. G. (1998) Anarkhiia i poriadok v kontekste rossiiskogo postkommunisticheskogo razvitiia [Anarchy and order in the context of post-Communist development in Russia]. Voprosy filosofii, no. 5, pp. 3-20. (In Russ.).

Filatova, N. G. (2011) O kontseptual'nykh osnovaniiakh izucheniia fenomena dukhovnosti [On the conceptual basis of examining the phenomenon of spirituality]. In: Ekonomika, finansy $i$ upravlenie $v$ sovremennykb usloviiakb [Contemporary economics, finances and management] : A collection of articles. Issue 7 (9) / ed. by A. N. Sorochaikin. Samara, Samara University Publ. 234 p. Pp. 184-192. (In Russ.).

Shorokhova, M. A. (2014) Svoboda vybora i dukhovnaia svoboda v kontekste problemy kachestva zhizni [Freedom of choice and spiritual freedom in the context of the problem of quality of life]. Izvestiia Volgogradskogo gosudarstvennogo pedagogicheskogo universiteta no. 8 (93), pp. 54-58. (In Russ.).

Shtumpf, S. P. (2014) Kontseptual'naia model' dukhovnosti: soderzhatel'nyi kontent, struktura, mekhanizmy realizatsii [A conceptual model of spirituality: Content, structure and the mechanism of implementation]. Vestnik Krasnoiarskogo gosudarstvennogo pedagogicheskogo universiteta im. V. P. Astafieva, no. 3 (29), pp. 178-182. (In Russ.).

Shugurov, M. V. (2013) Sootnoshenie smysla i nebytiia v antropologicheskoi ontogermenevtike: kul'turo-filosofskie proektsii [The correlation between sense and non-existence in the anthropological onto-hermeneutics: Cultural and philosophical views]. Filosofiia $i$ kul'tura, no. 10, pp. 1353-1367. (In Russ.).

Yankovskaia, L. V. (2014) Dukhovnost' v kul'ture i filosofii: v preddverii integral'nogo sinteza $\mathrm{v}$ ponimanii dukhovnosti [Spirituality in culture and philosophy: Anticipating an integral synthesis in understanding the spirituality]. Kul'tura $i$ vremia peremen, no. 3 (6), pp. 138-142. (In Russ.).

Submission date: 23.07 .2015$.

Шугуров Марк Владимирович - доктор философских наук, профессор кафедры философии Саратовской государственной юридической академии. Адрес: 410056, Россия, г. Саратов, ул. Вольская, д. 1, корп. 5, каб.621. Тел.:+7 (8452) 29-90-27. Эл. адрес: shugurovs@mail.ru

Shugurov Mark Vladimirovich, Doctor of Philosophy, Professor, Department of Philosophy, Saratov State Law Academy. Postal address: Office 621, Bldg. 5, 1 Volskaya St., 410056 Saratov, Russian Federation. Tel.: +7 (8452) 29-90-27. E-mail:shugurovs@mail.ru 